\title{
PRESERVATION OF THE WILD ANIMALS OF NORTH AMERICA
}

\section{BY HENRY FAIRFIELD OSBORN}

\section{N}

ADDRESS BEFORE THE BOONE AND CROCKETT CLUB, WASHINGTON, JANUARY 23, 1904 


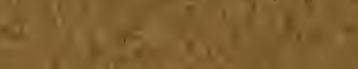

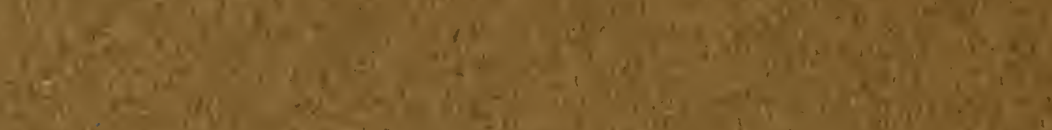

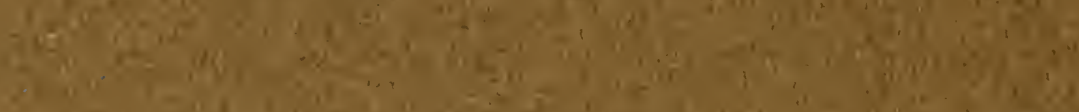

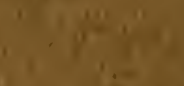

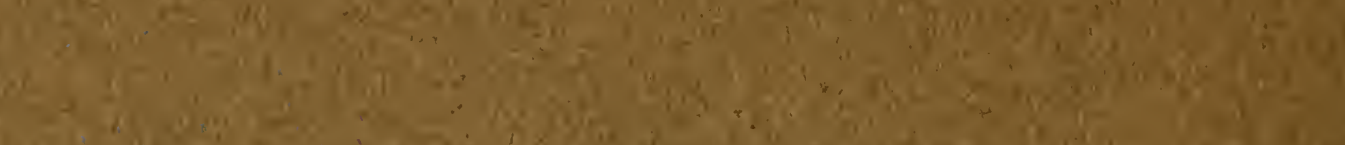

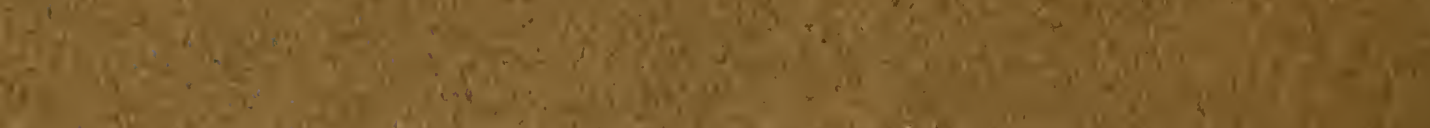

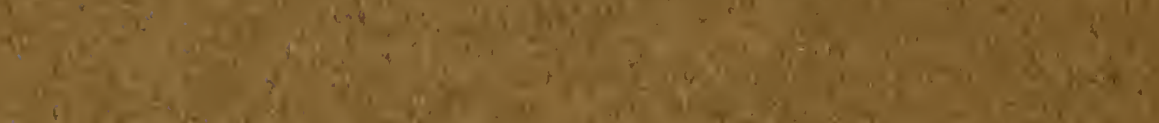

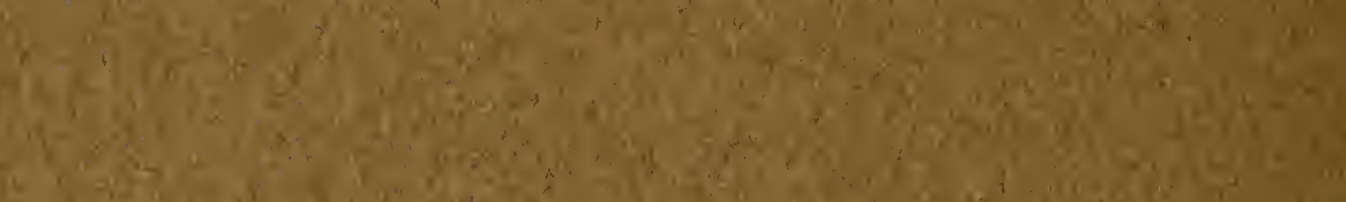

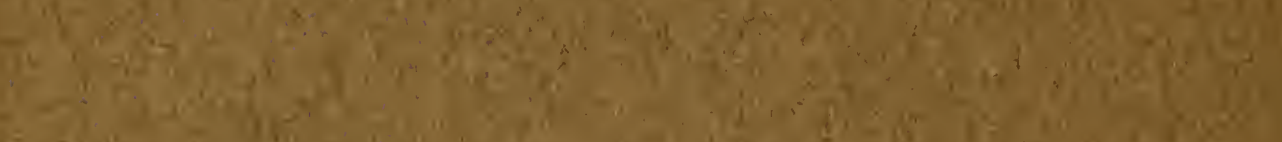

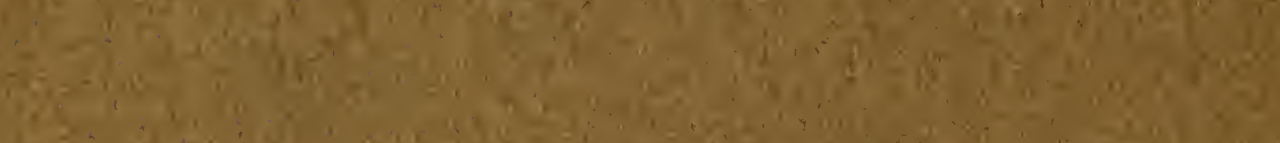
$1=$

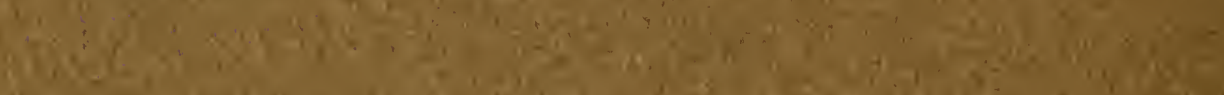

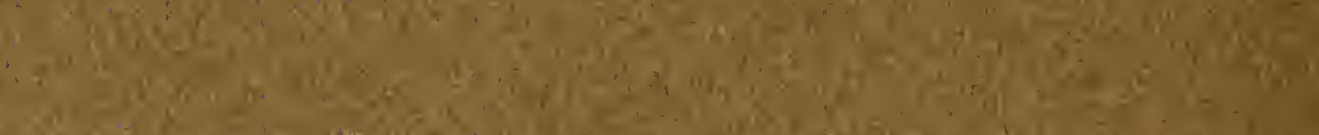

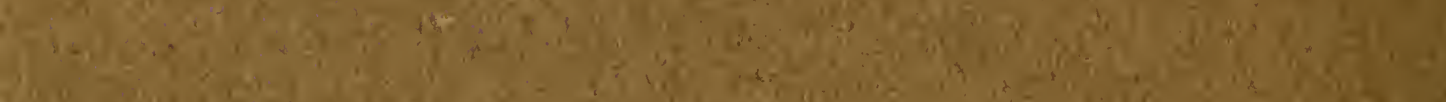

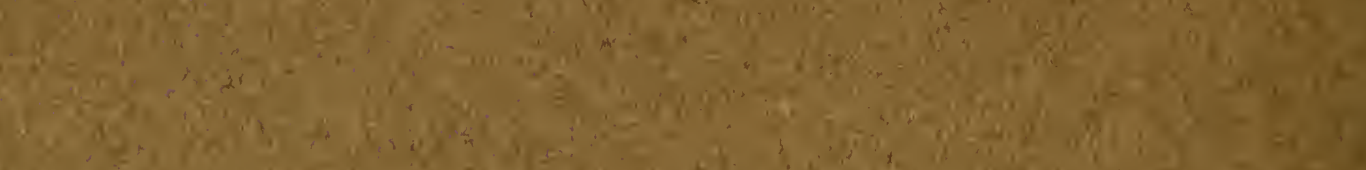

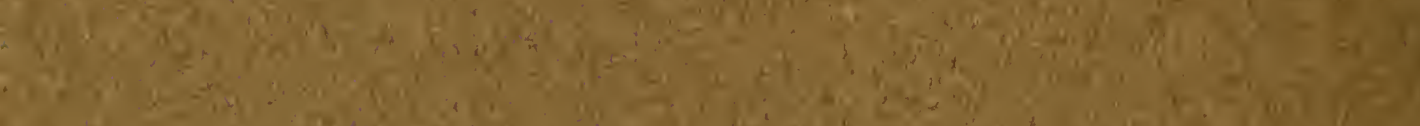

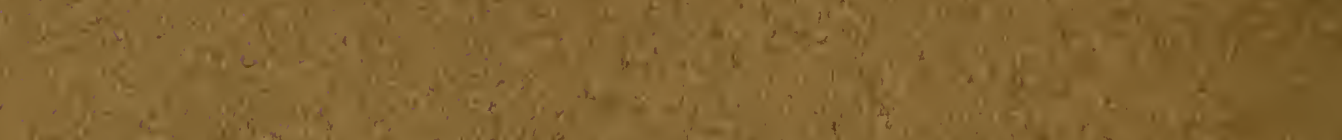

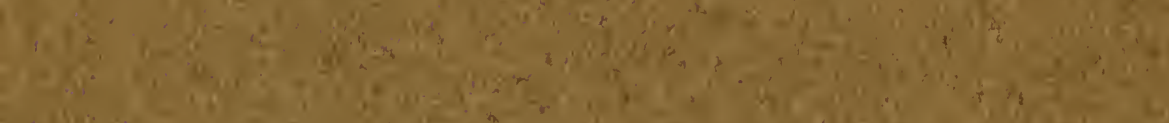

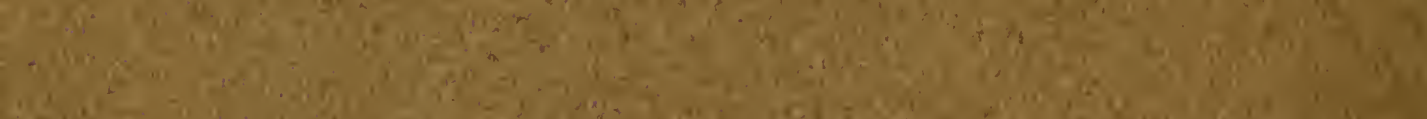

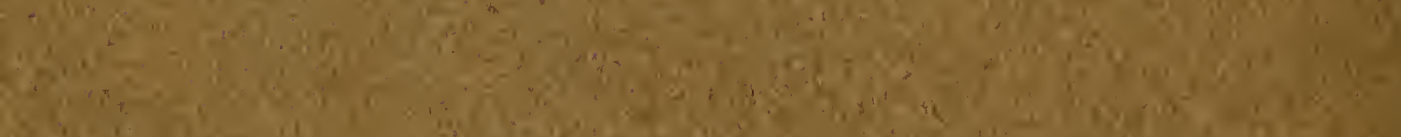

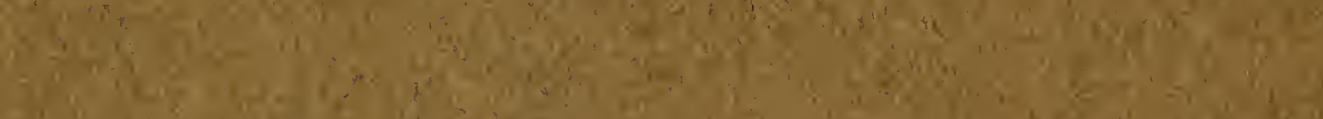

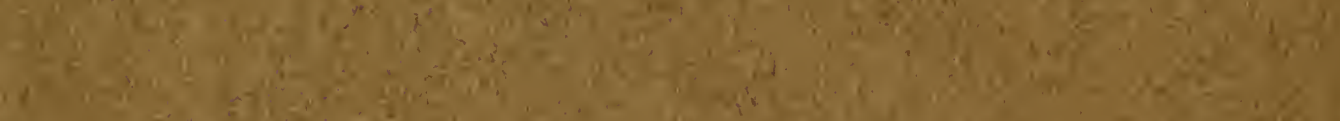

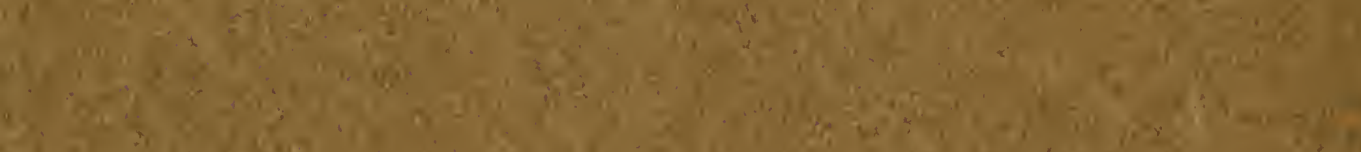

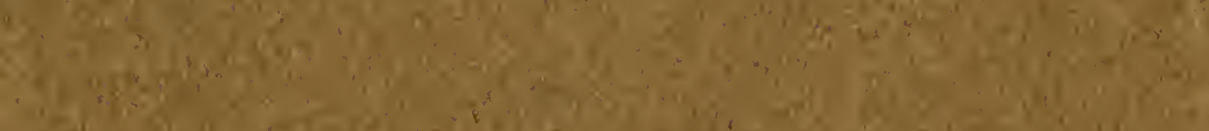

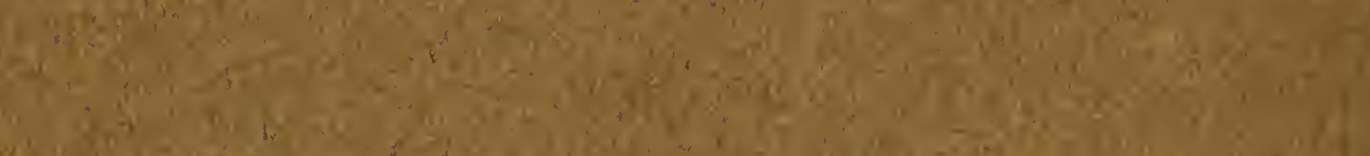

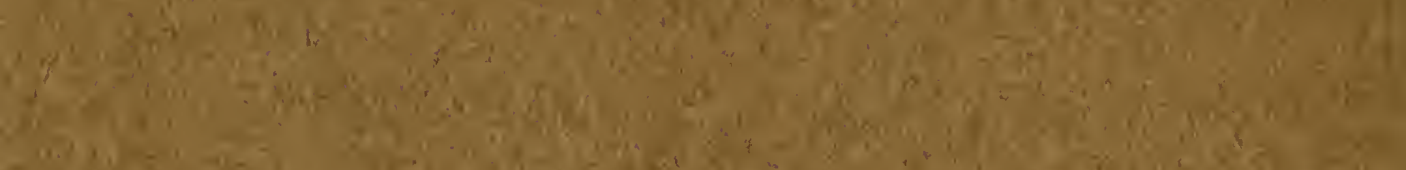

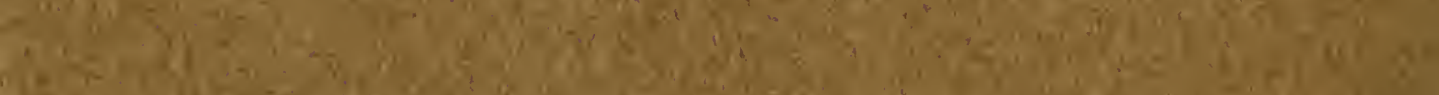
6.

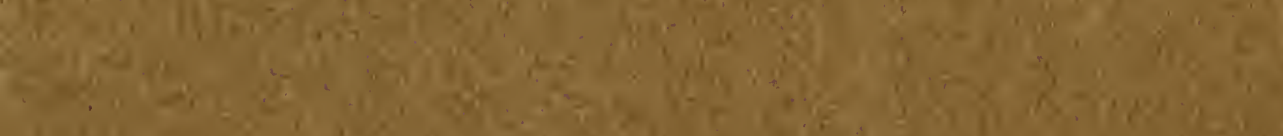

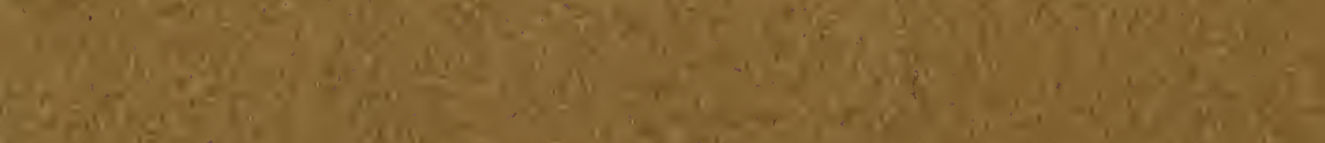

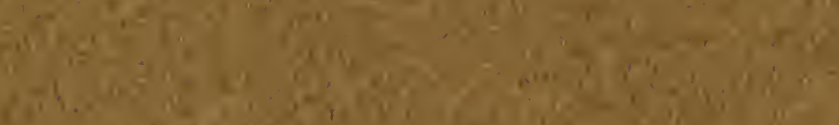

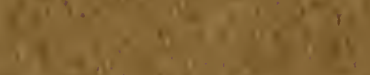

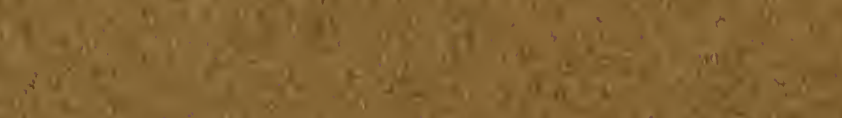

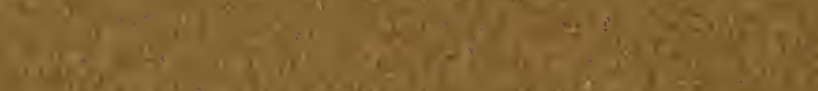

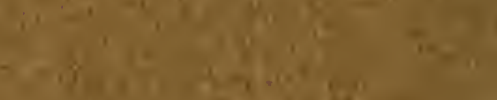






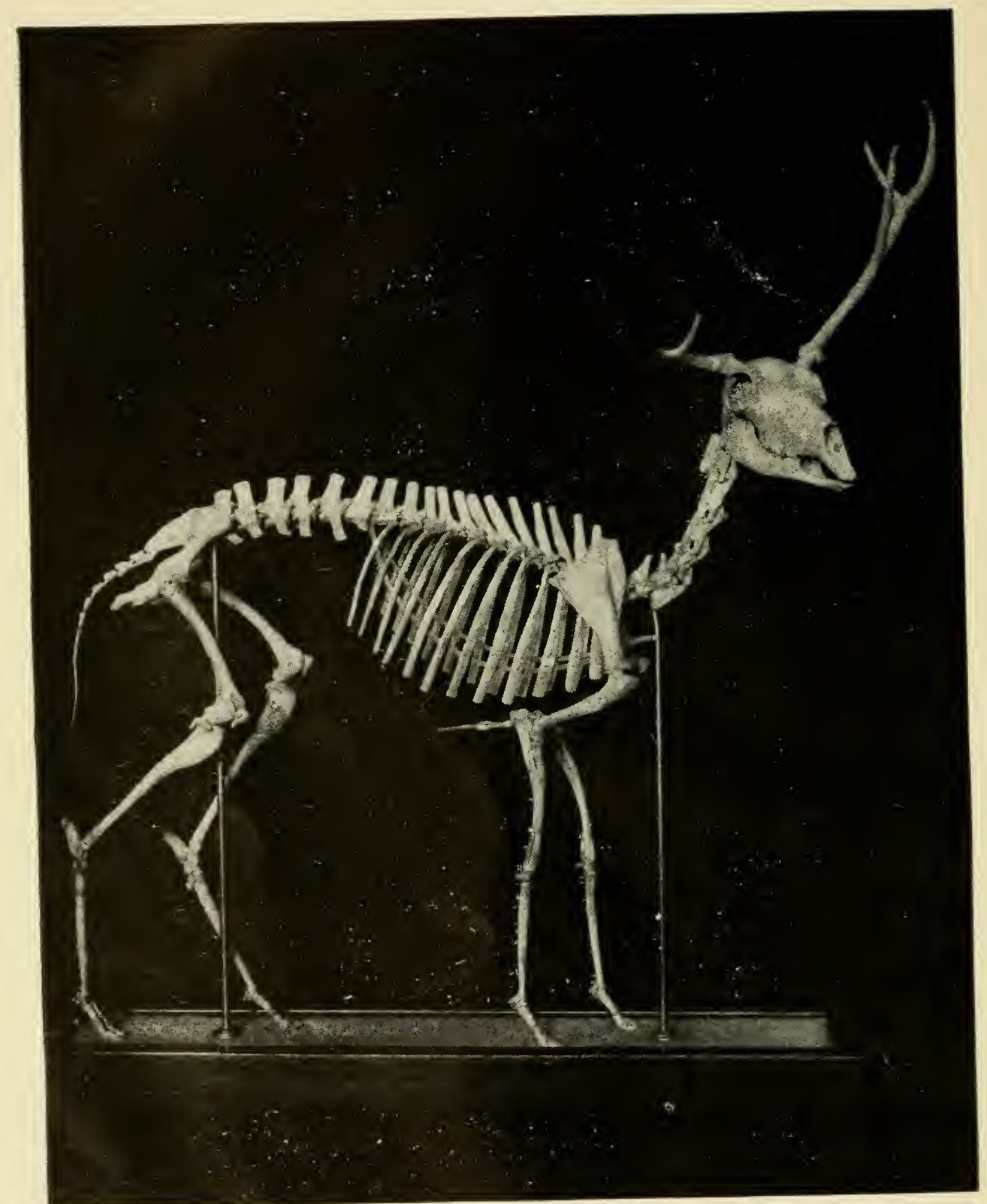

Merycodus osbormi MATTHEW.

From the Middle Miocene of Colorado. Discovered and described by Dr. W. D. Matthew. Mnunted by Mr. Adam Hermann. 


\section{PRESERVATION OF THE WILD ANIMALS OF NORTH AMERICA}

By HENRY FAIRFIELD OSBORN 
$\because$

$$
6-23930
$$


Preservation of the Wild Animals of North America

BY HENRY FAIRFIELD OSBORN.

The National and Congressional movement for the preservation of the Sequoia in California represents a growth of intelligent sentiment. It is the same kind of sentiment which must be aroused, and aroused in time, to bring about Government legislation if we are to preserve our native animals. That which principally appeals to us in the Sequoia is its antiquity as a race, and the fact that California is its last refuge.

As a special and perhaps somewhat novel argument for preservation, I wish to remind you of the great antiquity of our game animals, and the enormous period of time which it has taken nature to produce them. We must have legislation, and we must have it in time. I recall the story of the judge and jury who arrived in town and inquired about the security of the prisoner, who was known to be a desperate character; they were assured by 
the crowd that the prisoner was perfectly secure because he was safely hanging to a neighboring tree. If our preservative measures are not prompt, there will be no animals to legislate for.

\section{SENTIMENT AND SCIENCE.}

The sentiment which promises to save the Sequoia is due to the spread of knowledge regarding this wonderful tree, largely through the efforts of the Division of Forestry. In the official chronology of the United States Geological Surveywhich is no more nor less reliable than that of other geological surveys, because all are alike mere approximations to the truth-the Sequoia was a well developed race 10,000,000 of years ago. It became one of a large family, including fourteen genera. The master genus-the Sequoia -alone includes thirty extinct species. It was distributed in past times through Canada, Alaska, Greenland, British Columbia, across Siberia, and down into southern Europe. The Ice Age, and perhaps competition with other trees more successful in seeding down, are responsible for the fact that there are now only two living species-the "red wood," or Sequoia sempervirens, and the giant, or Sequoia gigantea. The last refuge of the gigantea is in ten isolated groves, in some of 


\section{Animals of North America}

which the tree is reproducing itself, while in others it has ceased to reproduce.

In the year I 900 forty mills and logging companies were engaged in destroying these trees.

All of us regard the destruction of the Parthenon by the Turks as a great calamity; yet it would be possible, thanks to the laborious studies which have chiefly emanated from Germany, for modern architects to completely restore the Parthenon in its former grandeur; but it is far beyond the power of all the naturalists of the world to restore one of these Sequoias, which were large trees, over IOO feet in height, spreading their leaves to the sun, before the Parthenon was even conceived by the architects and sculptors of Greece.

LIFE OF THE SEQUOIA AND HISTORY OF THOUGHT.

In I 900 five hundred of the very large trees still remained, the highest reaching from 320 to 325 feet. Their height, however, appeals to us less than their extraordinary age, estimated by Hutchins at 3,600 , or by John Muir, who probably loves them more than any man living, at from 4,000 to 5,000 years. According to the actual count of Muir of 4,000 rings, by a method which he has described to me, one of these trees was I,000 years old when Homer wrote the Iliad; 


\section{Preservation of the Wild}

I,500 years of age when Aristotle was foreshadowing his evolution theory and writing his history of animals; 2,00o years of age when Christ walked upon the earth; nearly 4,000 years of age when the "Origin of Species" was written. Thus the life of one of these trees spanned the whole period before the birth of Aristotle $(384$ B. C.) and after the death of Darwin (A. D. I882), the two greatest natural philosophers who have lived.

These trees are the noblest living things upon earth. I can imagine that the American people are approaching a stage of general intelligence and enlightened love of nature in which they will look back upon the destruction of the Sequoia as a blot on the national escutcheon.

\section{VENERATION OF AGE.}

The veneration of age sentiment which should, and I believe actually does, appeal to the American people when clearly presented to them even more strongly than the commercial sentiment, is roused in equal strength by an intelligent appreciation of the race longevity of the larger animals which our ancestors found here in profusion, and of which but a comparatively small number still survive. To the unthinking man a bison, a wapiti, a deer, a pronghorn antelope, is a matter of hide 


\section{Animals of North America}

and meat; to the real nature lover, the true sportsman, the scientific student, each of these types is a subject of intense admiration. From the mechanical standpoint they represent an architecture more elaborate than that of Westminster Abbey, and a history beside which human history is as of yesterday.

\section{SLOW EVOLUTION OF MODERN MAMMALS.}

These animals were not made in a day, nor in a thousand years, nor in a million years. As said the first Greek philosopher, Empedocles, who 560 B. C. adumbrated the "survival of the fittest" theory of Darwin, they are the result of ceaseless trials of nature. While the Sequoia was first emerging from the Carboniferous, or Coal Period, the reptile-like ancestors of these mammals, covered with scales and of egg-laying habits, were crawling about and giving not the most remote prophecy of their potential transformation through Io,000,000 of years into the superb fauna of the northern hemisphere.

The descendants of these reptiles were transformed into mammals. If we had had the opportunity of studying the early mammals of the Rocky Mountain region with a full appreciation of the possibilities of evolution, we should have 


\section{Preservation of the Wild}

perceived that they were essentially of the same stock and ancestral to our modern types. There were little camels scarcely more than twelve inches high, little taller than cotton-tail rabbits and smaller than the jackass rabbits; horses 15 inches high, scarcely larger than, and very similar in build to, the little English coursing hound known as the whippet; it is not improbable that we shall find the miniature deer; there certainly existed ancestral wolves and foxes of similarly small proportions. You have all read your Darwin carefully enough to know that neither camels, horses, nor deer would have evolved as they did except for the stimulus given to their limb and speed development by the contemporaneous evolution of their enemies in the dog family.

THE MIDDLE STAGE OF EVOLUTION.

A million and a half years later these same animals had attained a very considerable size; the western country had become transformed by the elevation of the plateaux into dry, grass-bearing uplands, where both horses and deer of peculiarly American types were grazing. We have recently secured some fresh light on the evolution of the American deer. Besides the Palcomeryx, which may be related to the true American deer Odocoi- 


\section{Animals of North America}

leus, we have found the complete skeleton of a small animal named Merycodus, nineteen inches high, possessed of a complete set of delicate antlers with the characteristic burr at the base indicating the annual shedding of the horn, and a general structure of skeleton which suggests our socalled pronghorn antelope, Antilocapra, rather than our true American deer, Odocoileus. This was in all probability a distinctively American type. Its remains have been found in eastern Colorado in the geological age known as Middle Miocene, which is estimated (sub rosa, like all our other geological estimates), at about a million and a half years of age. Our first thought as we study this small, strikingly graceful animal, is wonder that such a high degree of specialization and perfection was reached at so early a period; our second thought is the reverence for age sentiment.

\section{THE AFRICAN PERIOD IN AMERICA.}

The conditions of environment were different from what they were before or what they are now. These animals flourished during the period in which western America must have closely resembled the eastern and central portions of Africa at the present time. 


\section{Preservation of the Wild}

This inference is drawn from the fact that the predominant fauna of America in the Middle and Upper Miocene Age and in the Pliocene was closely analogous to the still extant fauna of Africa. It is true we had no real antelopes in this country, in fact none of the bovines, and no giraffes; but there was a camel which my colleague Matthew has surnamed the "giraffe camel," extraordinarily similar to the giraffe. There were no hippopotami, no hyraces. All these peculiarly African animals, of African origin, I believe, found their way into Europe at least as far as the Sivalik Hills of India, but never across the Bering Sea Isthmus. The only truly African animal which reached America, and which flourished here in an extraordinary manner, was the elephant, or rather the mastodon, if we speak of the elephant in its Miocene stage of evolution. However, the resemblance between America and Africa is abundantly demonstrated by the presence of great herds of horses, of rhinoceroses, both long and short limbed, of camels in great variety, including the giraffe-like type which was capable of browsing on the higher branches of trees, of small elephants, and of deer, which in adaptation to somewhat arid conditions imitated the antelopes in general structure. 


\section{Animals of North America}

ELIMINATION BY THE GLACIAL PERIOD.

The Glacial Period eliminated half of this fauna, whereas the equatorial latitude of the fauna in Africa saved that fauna from the attack of the Glacial Period, which was so fatally destructive to the animals in the more northerly latitudes of America. The glaciers or at least the very low temperature of the period eliminated especially all the African aspects of our fauna. This destructive agency was almost as baneful and effective as the mythical Noah's flood. When it passed off, there survived comparatively few indigenous North American animals, but the country was repopulated from the entire northern hemisphere, so that the magnificent wild animals which our ancestors found here were partly North American and partly Eurasiatic in origin.

\section{ELIMINATION BY MAN.}

Our animal fortune seemed to us so enormous that it never could be spent. Like a young rake coming into a very large inheritance, we attacked this noble fauna with characteristic American improvidence, and with a rapidity compared with which the Glacial advance was eternally slow; the East went first, and in fifty years we have brought about an elimination in the West which 


\section{Preservation of the Wild}

promises to be even more radical than that effected by the ice. We are now beginning to see the end of the North American fauna; and if we do not move promptly, it will become a matter of history and of museums. The bison is on the danger line; if it survives the fatal effects of its natural sluggishness when abundantly fed, it still runs the more insidious but equally great danger of inbreeding, like the wild ox of Europe. The chances for the wapiti and elk and the western mule and black-tail deer are brighter, provided that we move promptly for their protection. The pronghorn is a wonderfully clever and adaptive animal, crawling under barb-wire fences, and thus avoiding one of the greatest enemies of Western life. Last summer I was surprised beyond measure to see the large herds of twenty to forty pronghorn antelopes still surviving on the Laramie plains, fenced in on all sides by the wires of the great Four-Bar Ranch, part of which I believe are stretched illegally.

\section{RECENT DISAPPEARANCE.}

I need not dwell on the astonishingly rapid diminution of our larger animals in the last few years; it would be like "carrying coals to New. castle" to detail personal observations before this 


\section{Animals of North America}

Club, which is full of men of far greater experience and knowledge than myself. On the White River Plateau Forest Reserve, which is destined to be the Adirondacks of Colorado, with which many of you are familiar, the deer disappeared in a period of four years. Comparatively few are left.

The most thoroughly devastated country I know of is the Uintah Mountain Forest Reserve, which borders between southwestern Wyoming and northern Utah. I first went through this country in 1877 . It was then a wild natural region; even a comparatively few years ago it was bright with game, and a perfect flower garden. It has felt the full force of the sheep curse. I think any one of you who may visit this country now will agree that this is not too strong a term, and I want to speak of the sheep question from three standpoints: First, as of a great and legitimate industry in itself; second, from the economic standpoint; third, from the standpoint of wild animals.

\section{GENERAL RESULTS OF GRAZING.}

The formerly beautiful Uintah Mountain range presents a terrible example of the effects of prolonged sheep herding. The under foliage is en- 


\section{Preservation of the Wild}

tirely gone. The sheep annually eat off the grass tops and prevent seeding down; they trample out of life what they do not eat; along the principal valley routes even the sage brush is destroyed. Reforesting by the upgrowth of young trees is still going on to a limited extent, but is in danger. The water supply of the entire Bridger farming country, which is dependent upon the Uintah Mountains as a natural reservoir, is rapidly diminishing; the water comes in tremendous floods in the spring, and begins to run short in the summer, when it is most needed. The consequent effects upon both fish and wild animals are well known to you. No other animal will feed after the sheep. It is no exaggeration to say, therefore, that the sheep in this region are the enemies of every living thing.

\section{BALANCE OF NATURE.}

Even the owner cannot much longer enjoy his range, because he is operating against the balance of nature. The last stage of destruction which these innocent animals bring about has not yet been reached, but it is approaching; it is the stage in which there is no food left for the sheep themselves. I do not know how many pounds of food a sheep consumes in course of a year-it cannot be much less than a ton-but say it is only half a ton, 
how many acres of dry western mountain land are capable of producing half a ton a year when not seeding down? As long as the consumption exceeds the production of the soil, it is only a question of time when even the sheep will no longer find subsistence.

THE LAST STAGE TO BE SEEN IN THE ORIENT.

While going through these mountains last summer and reflecting upon the prodigious changes which the sheep have brought about in a few years, it occurred to me that we must look to Oriental countries in order to see the final results of sheep and goat grazing in semi-arid climates. I have proposed as an historical thesis a subject which at first appears somewhat humorous, namely, "The Influence of Sheep and Goats in History." I am convinced that the country lying between Arabia and Mesopotamia, which was formerly densely populated, full of beautiful cities, and heavily wooded, has been transformed less by the action of political causes than by the unrestricted browsing of sheep and goats. This browsing destroyed first the undergrowth, then the forests, the natural reservoirs of the country, then the grasses which held together the soil, and finally resulted in the removal of the soil itself. 


\section{Preservation of the Wild}

The country is now denuded of soil, the rocks are practically bare; it supports only a few lions, hyænas, gazelles, and Bedouins. Even if the trade routes and mines, on which Brooks Adams in his "New Empire" dwells so strongly as factors of all civilization, were completely restored, the population could not be restored nor the civilization, because there is nothing in this country for people to live upon. The same is true of North Africa, which, according to Gibbon, was once the granary of the Roman Empire. In Greece to-day the goats are now destroying the last vestiges of the forests.

I venture the prediction that the sheep industry on naturally semi-arid lands is doomed; that the future feeding of both sheep and cattle will be on irrigated lands, and that the forests will be carefully guarded by State and Nature as natural reservoirs.

\section{COMMERCIALISM AND IDEALISM.}

By contrast to the sheep question, which is a purely economic or utilitarian one, and will settle itself, if we do not settle it by legislation based on scientific observation, the preservation of the Sequoia and of our large wild animals is one of pure sentiment, of appreciation of the ideal side 


\section{Animals of North America}

of life; we can live and make money without either. We cannot even use the argument which has been so forcibly used in the case of the birds, that the cutting down of these trees or killing of these animals will upset the balance of nature.

I believe in every part of the country-East, West, North, and South-we Americans have reached a stage of civilization where if the matter were at issue the majority vote would unquestionably be, let us preserve our wild animals.

We are generally considered a commercial people, and so we are; but we are more than this, we are a people of ideas, and we value them. As stated in the preamble of the Sequoia bill introduced on Dec. 8, 1903, we must legislate for the benefit and enjoyment of the people, and I may add for the greatest happiness of the largest number, not only of the present but of future generations.

So far as my observation goes, preservation can only be absolutely insured by national legislation.

GOVERNMENT LEGISLATION BY ENGLAND,

BELGIUM, GERMANY.

The English, a naturally law-abiding people, seem to have a special faculty for enforcing laws. By co-operation with the Belgian Government they have taken effective and remarkably success- 


\section{Preservation of the Wild}

ful measures for the protection of African game. As for Germany, in I $896 \mathrm{Mr}$. Gosselin, of the British Embassy in Berlin, reported as follows for German East Africa:

That the question of preserving big game in German East Africa has been under the consideration of the local authorities for some time past, and a regulation has been notified at Dar-es-Salaam which it is hoped will do something toward checking the wanton destruction of elephants and other indigenous animals. Under this regulation every hunter must take out an animal license, for which the fee varies from 5 to 500 rupees, the former being the ordinary fee for natives, the latter for elephant and rhinoceros hunting, and for the members of sporting expeditions into the interior. Licenses are not needed for the purpose of obtaining food, nor for shooting game damaging cultivated land, nor for shooting apes, beasts of prey, wild boars, reptiles, and all birds except ostriches and cranes. Whatever the circumstances, the shooting is prohibited of all young game-calves, foals, young elephants, either tuskiess or having tusks under three kilos, all female game if recognizable-except, of course, those in the above category of unprotected animals. Further, in the Moschi district of Kilima-Njaro, no one, whether possessing a license or not, is allowed without the special permission of the Governor to shoot antelopes, giraffes, buffaloes, ostriches, and cranes. Further, special permission must be obtained to hunt 


\section{Animals of North America}

these with nets, by kindling fires, or by big drives. Those who are not natives have also to pay Ioo rupees for the first elephant killed, and 250 for each additional one, and 50 rupees for the first rhinoceros and $I_{5}$ for each succeeding one. Special game preserves are also to be established, and Major von Wissmann, in a circular to the local officers, explains that no shooting whatever will be allowed in these without special permission from the Government. The reserves will be of interest to science as a means of preserving from extirpation the rarer species, and the Governor calls for suggestions as to the best places for them. They are to extend in each direction at least ten hours' journey on foot. He further asks for suggestions as to hippopotamus reserves, where injury would not be done to plantations. Two districts are already notified as game sanctuaries. Major von Wissmann further suggests that the station authorities should endeavor to domesticate zebras (especially when crossed with muscat and other asses and horses), ostriches, and hyæna dogs crossed with European breeds. Mr. Gosselin remarks that the best means of preventing the extermination of elephants would be to fix by international agreement among all the Powers on the East African coast a close time for elephants, and to render illegal the exportation or sale of tusks under a certain age.

In December, I900, Viscount Cranborne in the House of Commons reported as follows: 


\section{Preservation of the Wild}

* * * That regulations for the preservation of wild animals have been in force for some time in the several African Protectorates administered by the Foreign Office as well as in the Sudan. The obligations imposed by the recent London Convention upon the signatory Powers will not become operative until after the exchange of ratifications, which has not yet taken place. In anticipation, however, steps have been taken to revise the existing regulations in the British Protectorates so as to bring them into strict harmony with the terms of the convention. The game reserves now existing in the several Protectorates are: In (a) British Central Africa, the elephant marsh reserve and the Shirwa reserve; in (b) the East Africa Protectorate, the Kenia District; in (c) Uganda, the Sugota game reserve in the northeast of the Protectorate; in (d) Somaliland, a large district defined by an elaborate boundary line described in the regulations. The regulations have the force of law in the Protectorates, and offenders are dealt with in the Protectorate Courts. It is in contemplation to charge special officers of the Administrations with the duty of watching over the proper observance of the regulations. Under the East African game regulations only the officers permanently stationed at or near the Kenia reserve may be specially authorized to kill game in the reserve.

Other effective measures have been taken in the Soudan district. Capt. Stanley Flower, Director 


\section{Animals of North America}

of the Gizeh Zoological Gardens, made a very full report, which is quoted in Nature for July 25, I 90 I, p. 3 I 8.

\section{STATE LAWS.}

The preservation of even a few of our wild animals is a very large proposition; it is an undertaking the difficulty of which grows in magnitude as one comes to study it in detail and gets on the ground. The rapidly increasing legislation in the Western States is an indication of rapidly growing sentiment. A still more encouraging sign is the strong sympathy with the enforcement of the laws which we find around the National Park in Wyoming and Montana especially. State laws should be encouraged, but I am convinced that while effective in the East, they will not be effective in the West in time, because of the scattered populationii, the greater areas of country involved, the greater difficulty of watching and controlling the killing, and the actual need of game for food by settlers.

When we study the operation of our State laws on the ground we find that for various reasons they are not fully effective. A steady and in some cases rapid diminution of animals is going on so far as I have observed in Colorado and Wyoming; 


\section{Preservation of the Wild}

either the wardens strictly enforce the laws with strangers and wink at the breaking of them by residents, or they draw their salaries and do not enforce the laws at all.*

\section{THE VARIOUS CAUSES OF ELIMINATION.}

The enemies of our wild animals are numerous and constantly increasing. (I) There is first the general advance of what we call civilization, the fencing up of country which principally cuts off the winter feeding grounds. This was especially

*Addendum.-There is no question as to the good intention of State legislation. The chief difficulty in the enforcement of the law is that officers appointed locally, and partly from political reasons, shrink from applying the penalties of the law to their own friends and neighbors, especially where the animals are apparently abundant and are sought for food. The honest enforcement of the law renders the officer unpopular, even if it does not expose him to personal danger. He is regarded as interfering with long established rights and customs. The above applies to conscientious officers. Many local game wardens, as in the Colorado White River Plateau, for example, give absolutely no attention to their duties, and are not even on the ground at the opening of the season. In the Plateau in August, 190r, the laws were being openly and flagrantly violated, not only by visitors, but by residents. At the same time the National forest laws were being most strictly and intelligently enforced. There is no question whatever that the people of various States can be brought to understand that National aid or co-operation in the protection of certain wild areas is as advantageous to a locality as National irrigation and National forest protection. It is to be sought as a boon and not as an infringement.

22

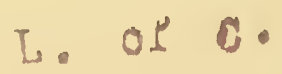




\section{Animals of North America}

seen in the country south of the National Park last winter. (2) The destruction of natural browsing areas by cattle and sheep, and by fire. (3) The destruction 'of game by sportsmen plays a comparatively small part in the total process of elimination, yet in some cases it is very reckless, and especially bad in its example. When I first rode into the best shooting country of Colorado in I90I, there was a veritable cannonading going on, which reminded me of the accounts of the battle of El Caney. The destruction effected by one party in three days was tremendous. In riding over the ground-for I was not myself shootingI was constantly coming across the carcasses of deer. (4) The summer and winter killing for food; this is the principal and in a sense the most natural and legitimate cause, although it is largely illegal. In this same area, which was more or less characteristic and typical of the other areas, even of the conditions surrounding the national reserve in the Big Horn region, the destruction was, and is, going on principally during the winter when the deer are seeking the winter ranges and when they are actually shot and carted away in large numbers for food both for the ranchmen and for neighboring towns. Making all allowances for exaggeration, I believe it to be absolutely true that these 


\section{Preservation of the Wild}

deer were being killed by the wagonload! The same is true of the pronghorn antelope in the Laramie Plains district. The most forceful argument against this form of destruction is that it is extremely short-lived and benefits comparatively few people. This argument is now enforced by law and by public sentiment in Maine and New York, where the wild animals, both deer and moose, are actually increasing in number.

Granted, therefore, that we have both National and State sentiment, and that National legislation by co-operation with the States, if properly understood, would receive popular support, the carrying out of this legislation and making it fully effective will be a difficult matter.

It can be done, and, in my judgment, by two measures. The first is entirely familiar to you: certain or all of the forest reserves must be made animal preserves; the forest rangers must be made game wardens, or special wardens must be appointed. This is not so difficult, because the necessary machinery is already at hand, and only requires adaptation to this new purpose. It can probably be carried through by patience and good judgment. Second, the matter of the preservation of the winter supply of food and protection of animals while enjoying this supply is the most difficult 


\section{Animals of North America}

part of the whole problem, because it involves the acquisition of land which has already been taken up by settlers and which is not covered by the present forest reserve machinery, and which I fear in many instances will require new legislation.

Animals can change their habits during the summer, and have already done so; the wapiti, buffalo, and even the pronghorn have totally changed their normal ranges to avoid their new enemy; but in winter they are forced by the heavy snows and by hunger right down into the enemy's country.

Thus we not only have the problem of making game preserves out of our forest reserves, but we have the additional problem of enlarging the area of forest reserves so as to provide for winter feeding. If this is not done all the protection which is afforded during the summer will be wholly futile. This condition does not prevail in the East, in Maine and in the Adirondacks, where the winter and summer ranges are practically similar. It is, therefore a new condition and a new problem.

Greater difficulties have been overcome, however, and I have no doubt that the members of this Club will be among the leaders in the movement. The whole country now applauds 


\section{Preservation of the Wild}

the development and preservation of the Yellowstone Park, which we owe largely to the initiative of Phillips, Grinnell, and Rogers. Grant and La Farge were pioneers in the New York Zoological Park movement. We know the work of Merriam and Wadsworth, and we always know the sympathies of our honored founder, member, and guest of this evening, Theodore Roosevelt.

What the Club can do is to spread information and thoroughly enlighten the people, who always act rightly when they understand.

It must not be put on the minutes of the history of America, a country which boasts of its popular education, that the Sequoia, a race 10,000,000 years old, sought its last refuge in the United States, with individual trees older than the entire history and civilization of Greece, that an appeal to the American people was unavailing, that the finest grove was cut up for lumber, fencing, shingles, and boxes! It must not be recorded that races of animals representing stocks $3,000,000$ years of age, mostly developed on the American continent, were eliminated in the course of fifty years for hides and for food in a country abounding in sheep and cattle.

The total national investment in animal preservation will be less than the cost of a single battle- 
Animals of North America

ship. The end result will be that a hundred years hence our descendants will be enjoying and blessing us for the trees and animals, while, in the other case, there will be no vestige of the battleship, because it will be entirely out of date in the warfare of the future. 





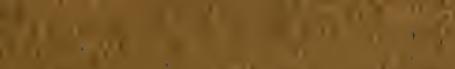

a.s.

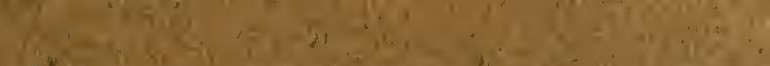

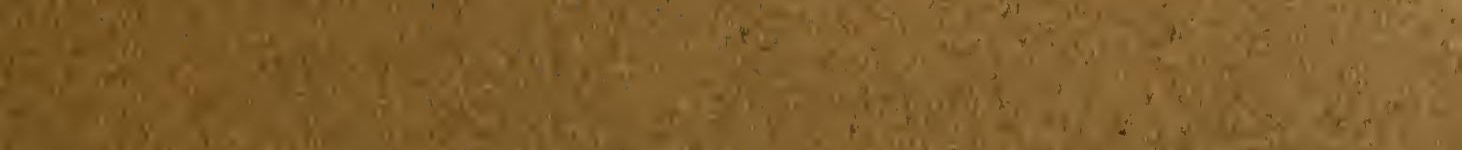

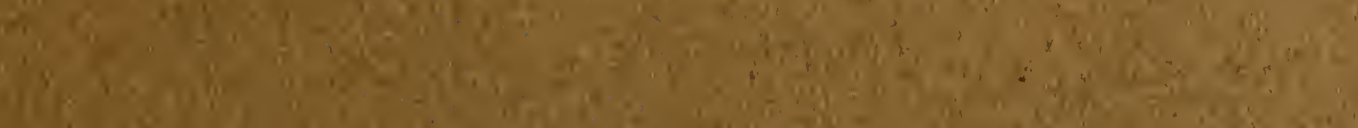

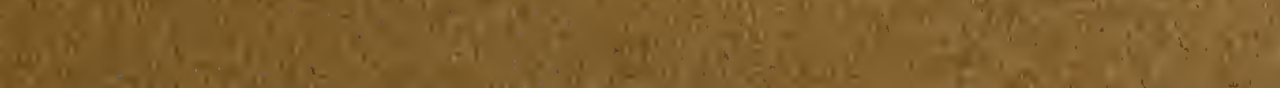

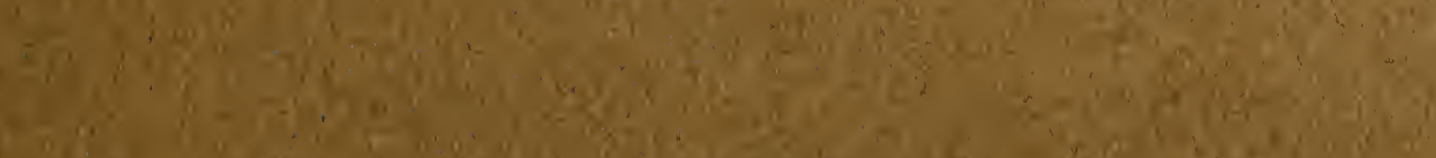

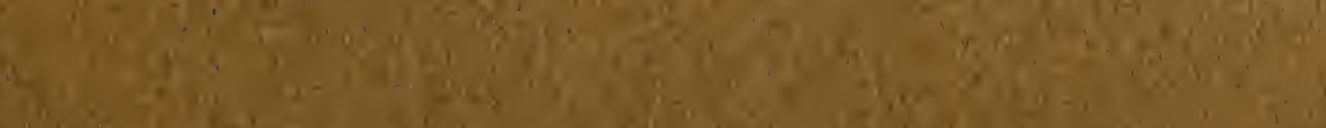

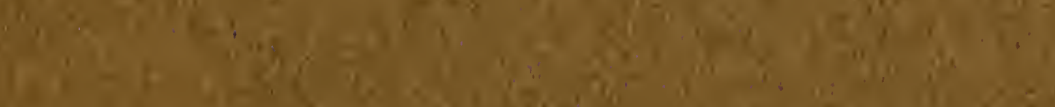

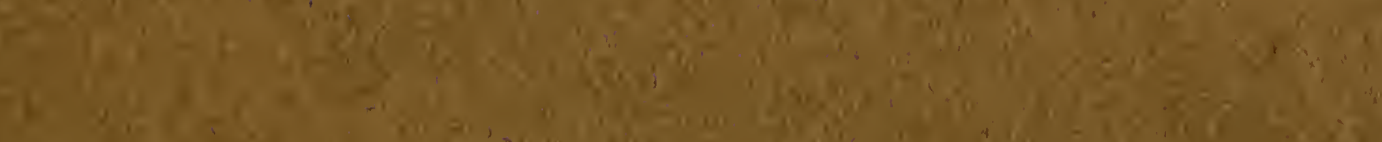

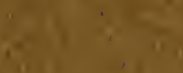

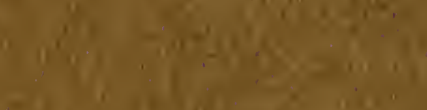
Min

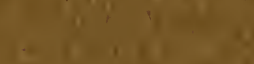

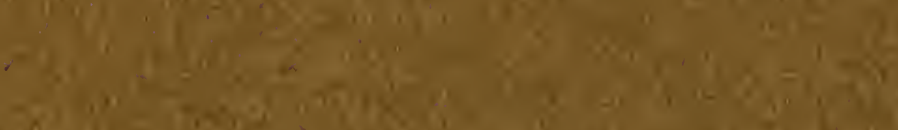

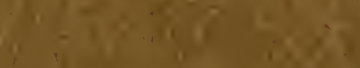

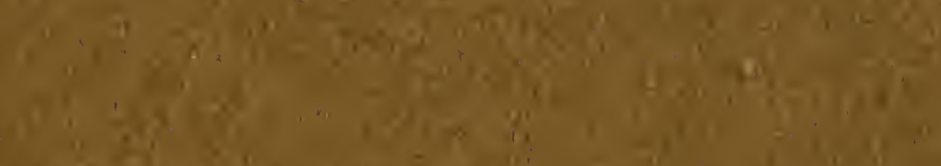

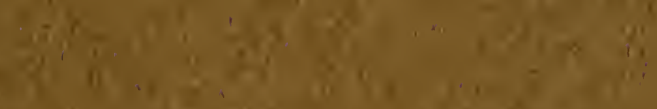

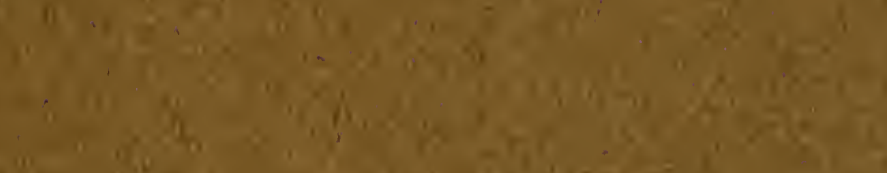

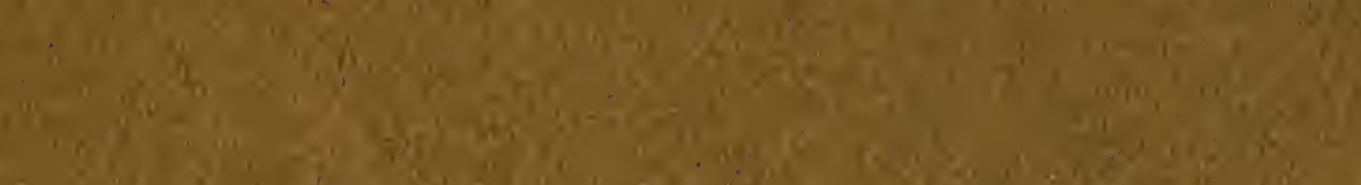

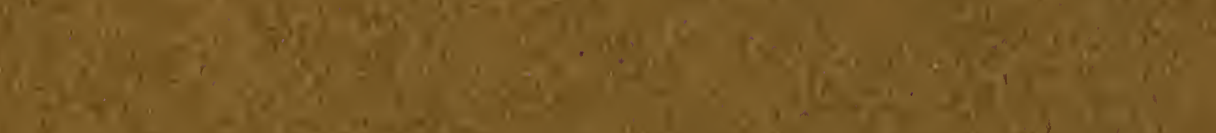

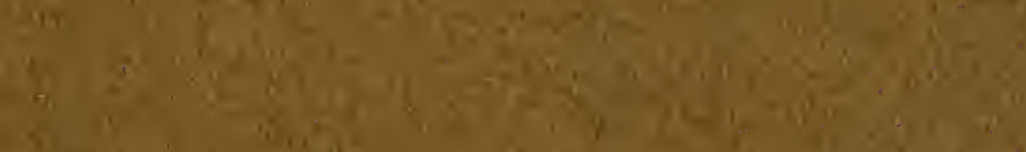

(4.

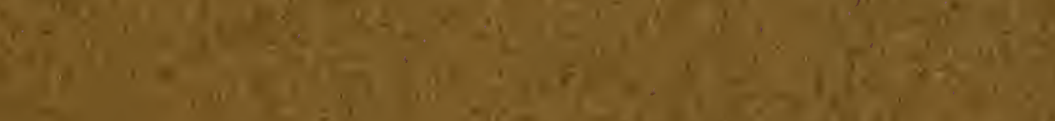

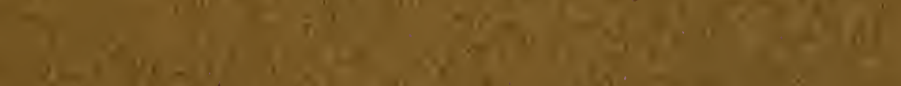

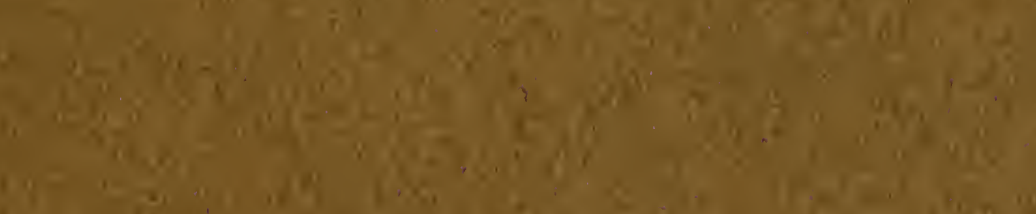

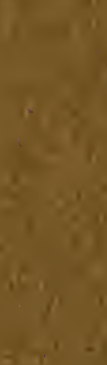

$y^{2}=2+2$

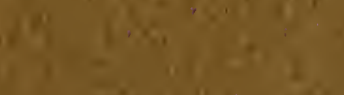

intis

$$
\cos ^{2} x^{2}=
$$

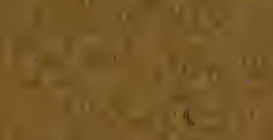

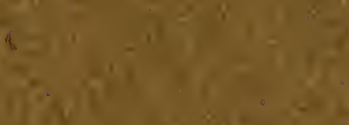

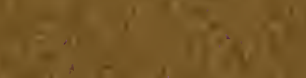

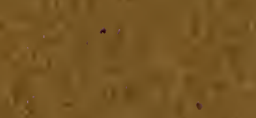
$3 x+y$

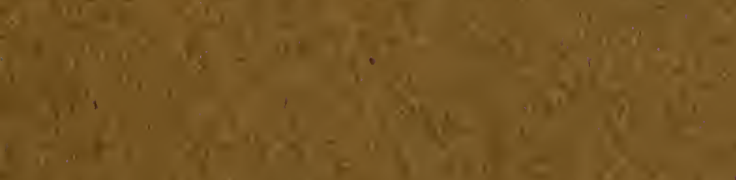

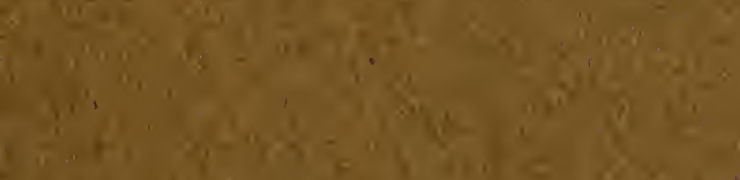

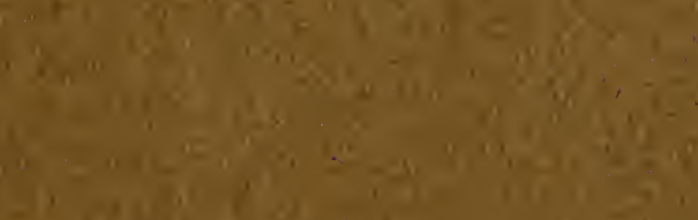

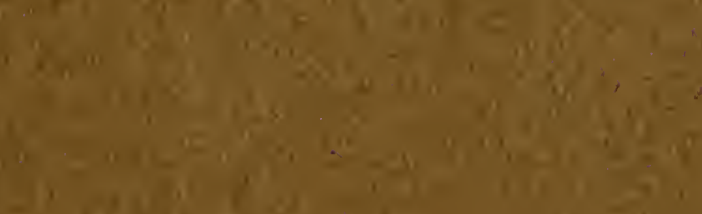

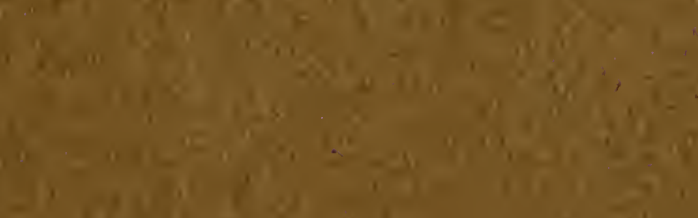

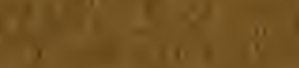

4.

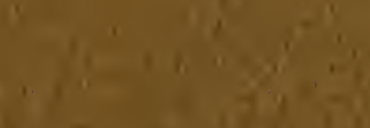

(3)

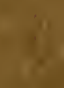
+4 $1.6=$

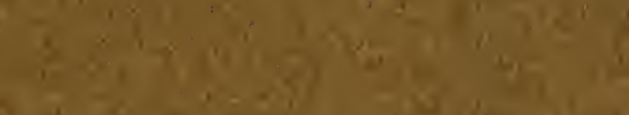

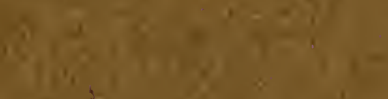
$e^{4}$ in $3 i^{2}=10$ $\forall n^{2} 16$

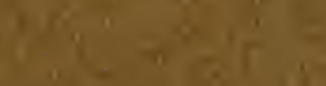
' 
